\title{
Lead acetate ecotoxicity in tropical soils
}

\author{
R. C. S. Alexandrino ${ }^{1}$ - F. R. D. Lima² - G. C. Martins ${ }^{3} \cdot$ T. Natal-da-Luz ${ }^{4}$ J. P. Sousa ${ }^{4}$ L. R. G. Guilherme ${ }^{2}$. \\ J. J. Marques $\mathbb{1}^{2}$
}

Accepted: 8 June 2021 / Published online: 30 June 2021

(c) The Author(s), under exclusive licence to Springer Science+Business Media, LLC, part of Springer Nature 2021

\begin{abstract}
Lead acetate $(\mathrm{AcPb})$ is an important raw material used in chemical industries worldwide. The potential toxicity of $\mathrm{AcPb}$ is generally attributed to the presence of $\mathrm{Pb}$. However, the effect of $\mathrm{AcPb}$ on the environment as a whole is still poorly known. This study aimed to evaluate $\mathrm{AcPb}$ toxicity on three standard species of soil invertebrates and two plant species using ecotoxicology tests. Three tropical soils (Oxisol, Inceptisol, and Tropical Artificial Soil (TAS)) were contaminated with different concentrations of $\mathrm{AcPb}$ and one dose of K-acetate (positive control). These soils were used in tests with Eisenia andrei (earthworm), Folsomia candida (springtail), Enchytraeus crypticus (enchytraeid), Zea mays (maize), and Phaseolus vulgaris (common bean). Dose-response curves obtained in the laboratory tests were used to estimate the $\mathrm{EC}_{50}$ values for each species. Among invertebrates, the highest sensitivity to $\mathrm{AcPb}$ was observed for E. crypticus in the $\mathrm{TAS}\left(\mathrm{EC}_{50}=\right.$ $\left.29.8 \mathrm{mg} \mathrm{AcPb} \mathrm{kg}^{-1}\right)$, whereas for $E$. andrei and F. candida the highest sensitivity was observed in the Oxisol $\left(\mathrm{EC}_{50}=141.9\right.$ and $1835 \mathrm{mg} \mathrm{AcPb} \mathrm{kg}^{-1}$, respectively). Folsomia candida was the least sensitive invertebrate species to $\mathrm{AcPb}$ in all soils. Among plant species, Z. mays was less sensitive $\left(\mathrm{EC}_{50}=1527.5 \mathrm{mg} \mathrm{AcPb} \mathrm{kg}{ }^{-1}\right)$ than $P$. vulgaris $\left(\mathrm{EC}_{50}=560.5 \mathrm{mg} \mathrm{AcPb}\right.$ $\mathrm{kg}^{-1}$ ) in the Oxisol. The present study evidenced that the toxicity of $\mathrm{AcPb}$ should not be attributed uniquely to the presence of $\mathrm{Pb}$, as the treatment containing uniquely Ac provoked the same toxicity as the highest dose of $\mathrm{AcPb}$.
\end{abstract}

Keywords Toxicity $\cdot$ Soil invertebrates $\cdot$ Crops $\cdot$ Phytotoxicity $\cdot$ Lead

\section{Highlights}

- Lead acetate significantly affected all standard species tested.

- Enchytraeus crypticus was the most sensitive species in all tested soils.

- Zea mays was less sensitive to AcPb than Phaseolus vulgaris.

- $\mathrm{K}$-acetate equivalent to the highest $\mathrm{AcPb}$ dose was as toxic as the highest $\mathrm{AcPb}$ dose.

Supplementary information The online version contains supplementary material available at https://doi.org/10.1007/s10646021-02443-0.

\section{J. J. Marques}

jmarques@ufla.br

1 Fundação Estadual do Meio Ambiente/Empresa de Pesquisa Agropecuária de Minas Gerais, 31630-900 Belo Horizonte, Brazil

2 Soil Science Department, Universidade Federal de Lavras, 37200900 Lavras, Minas Gerais, Brazil

3 Instituto Tecnológico Vale, 66055-090 Belém, Brazil

4 Centre for Functional Ecology, Department of Life Sciences, University of Coimbra, Calçada Martim de Freitas, 3000-456 Coimbra, Portugal

\section{Introduction}

Soil pollution is a current worldwide challenge that has direct and/or indirect impacts on human health, food security, environmental quality, provision of ecosystem services, and the economy (FAO 2018). Among the main types of pollutants to the environment are heavy metals, such as lead $(\mathrm{Pb})$, which stands out due to its potential harm and persistence in the environment (Wani et al. 2015; Frank et al. 2019; Verma et al. 2020).

Lead is an old and well-known public health hazard and is still responsible for poisoning hundreds of millions of children worldwide (Rees and Fuller 2020). The widespread number of sites contaminated by $\mathrm{Pb}$ is probably due to its historical and current broad use and human activities. For example, as a raw material in lead-acid batteries, some 
paints, glazes, leaded glass and ceramics, as well as mining, smelting, refining, and recycling of lead (WHO 2019; Rees and Fuller 2020). When these activities and products/wastes are not properly managed, there is an increased risk of environmental contamination with severe lasting implications.

The solubility of $\mathrm{Pb}$ compounds can be quite different, with lead acetate, lead chloride, and lead nitrate being among the most soluble Pb salts (NTP 2016). These soluble $\mathrm{Pb}$ compounds have many industrial uses, e.g., lead acetate $(\mathrm{AcPb})$ is used as a color additive in hair dyes; as a mordant in cotton dyes; in lead coating of metals; as a drier in paints; varnishes and pigment inks; and in medicines, such as astringents (NTP 2016; Pohanish 2017). Besides, AcPb has been used in the production of highly efficient perovskite solar cells ( $\mathrm{Li}$ et al. 2018, 2020) and on lead-acetate test paper, a product designed to detect sulfur in different materials (Selwyn 2017). All the uses mentioned above make it a potential source of soil contamination when proper management is not assigned.

Although lead is an element that has been widely studied (Brown et al. 2016; Rehman et al. 2017; Entwistle et al. 2019; Alexandrino et al. 2020), the knowledge on the disposal and detailed information on the exposure to materials containing $\mathrm{AcPb}$ for soil organisms is still limited. Moreover, the majority of the studies conducted to date to evaluate the toxicity of $\mathrm{Pb}$ to plants, invertebrates, and soil microorganisms have used nitrates and chlorides as a source of $\mathrm{Pb}$ (Sobolev and Begonia 2008; Xu et al. 2009; Smolders et al. 2015; Chandrasekhar and Ray 2019; Zhang et al. 2019a; Dai et al. 2020). To the best of our knowledge, most studies using $\mathrm{AcPb}$ as a $\mathrm{Pb}$ source have been devoted to assessing its toxicity in animals (Ibrahim et al. 2012; Haouas et al. 2014). The few studies using $\mathrm{AcPb}$ in soils have been focused mainly on the toxicity of $\mathrm{Pb}$ (Päivöke 2002; Liao et al. 2007; Zeng et al. 2007; Cândido et al. 2020). Consequently, data on $\mathrm{AcPb}$ toxicity to soil organisms are lacking, a useful piece of information on the management of areas contaminated by this $\mathrm{Pb}$ source.

Several studies investigated the toxicity of $\mathrm{AcPb}$ and evidenced its potential harm in soils (Liao et al. 2007; Zeng et al. 2007; Cândido et al. 2020). For example, Liao et al. (2007) showed that $\mathrm{AcPb}$ (concentrations $>500 \mathrm{mg} \mathrm{Pb} \mathrm{kg}^{-1}$ ) caused a significant decline in soil microbial biomass. Zeng et al. (2007) reported that concentrations up to $900 \mathrm{mg} \mathrm{Pb} \mathrm{kg}^{-1}$ as $\mathrm{AcPb}$ cause damage to rice plants, enzyme activity, and soil microbial biomass, and Cândido et al. (2020) found $\mathrm{Pb}$ concentrations of 2760 and $1788 \mathrm{mg} \mathrm{Pb} \mathrm{kg}{ }^{-1}$ (as $\mathrm{AcPb}$ ) that decrease the shoot dry matter production by $50 \%$ in sorghum and soybean, respectively. The wide range of effective concentrations presented for these studies shows that $\mathrm{Pb}$ toxicity can be quite different, considering the soil, test organisms, and endpoints evaluated.
It is widely known that distinct soils can induce dissimilar toxicities for the same concentration of a specific contaminant due to its interaction with soil attributes (Kabata-Pendias and Mukherjee 2007). Also, the exposure mode and own protection and detoxification strategies of each species also contribute to diversify the toxicity values, which reinforces the need to obtain toxicity data for different soils, organisms, and endpoints.

Whereas there is a lack of knowledge on the toxicity of $\mathrm{AcPb}$, mainly due to the stress caused by high concentrations of $\mathrm{AcPb}$ compared with acetate for plants and soil invertebrates, it becomes important to clarify the toxic effects of $\mathrm{AcPb}$ on these organisms. Ecotoxicological studies are needed to fill this gap and improve the understanding of $\mathrm{AcPb}$ effects on the environment, mainly for tropical soils, which may have physical and chemical attributes quite different from those found in temperate regions and standard substrates. Thus, this study aimed to evaluate $\mathrm{AcPb}$ and acetate toxicity in tropical soils through bioassays. It is expected that these results may clarify some aspects of $\mathrm{AcPb}$ toxicity in the tropical region.

\section{Materials and methods}

\section{Test soils}

In all experiments, two natural soils from areas of native vegetation with minimal anthropogenic interference of State of Minas Gerais, Brazil, were used: an Oxisol (Typic Hapludox) $\left(21^{\circ} 17^{\prime} 10.3^{\prime \prime} \mathrm{S}\right.$ and $\left.44^{\circ} 47^{\prime} 45.5^{\prime \prime} \mathrm{W}\right)$ and an Inceptisol (Typic Dystrudept) $\left(21^{\circ} 13^{\prime} 48.3^{\prime \prime} \mathrm{S}\right.$ and $44^{\circ} 59^{\prime}$ 11.6" W) (Soil Survey Staff 2014). Both soils were collected from the top 20-cm layer, air-dried, and sieved to $2 \mathrm{~mm}$. These soils were selected because Oxisols and Inceptisols are relevant soil classes in tropical regions, covering approximately 20 and $9 \%$ of the total area of South America, respectively (Gardi et al. 2015).

In tests with soil invertebrates, in addition to the natural soils, a Tropical Artificial Soil (TAS; Garcia et al. 2004) composed of a mixture of $75 \%$ fine sand, $20 \%$ kaolinite clay, and 5\% coconut fiber was used.

The physical and chemical properties of the natural soils are presented in Table 1. Briefly, soil $\mathrm{pH}$ was determined using a $1 \mathrm{~mol} \mathrm{~L}^{-1} \mathrm{KCl}$ solution (1:5, w-v; ISO-International Organizations for Standardization 2005), cation exchange capacity (CEC) was calculated by the sum of exchangeable cations and potential acidity according to Teixeira et al. (2017), the particle-size analysis was performed using the pipette method (Day 1965), water holding capacity was measured according to ISO 11269-2 (ISOInternational Organizations for Standardization 2005), and organic matter content was determined by the potassium 
Table 1 Physical and chemical properties of the Oxisol, Inceptisol, and Tropical Artificial Soil (TAS) used in laboratory experiments

\begin{tabular}{llll}
\hline Attributes & Oxisol & Inceptisol & TAS \\
\hline $\mathrm{pH}(\mathrm{KCl})$ & 4.3 & 4.9 & 5.0 \\
$\begin{array}{l}\text { Cation exchange capacity at } \mathrm{pH} \\
7\left(\mathrm{cmol}_{\mathrm{c}} \mathrm{dm}^{-3}\right)\end{array}$ & 5.0 & 6.1 & 2.3 \\
Water holding capacity (\%) & 40.0 & 59.0 & 49.0 \\
Organic matter $(\%)$ & 1.6 & 2.9 & 5.0 \\
Texture clay $(\%)$ & 23 & 46 & $20^{\mathrm{a}}$ \\
Silt $(\%)$ & 3 & 19 & 5 \\
Sand $(\%)$ & 74 & 35 & $75^{\mathrm{a}}$ \\
Texture class & Sandy & Clay & \\
& clay loam & & \\
\hline
\end{tabular}

${ }^{a}$ Value determined by weighing

dichromate $\left(\mathrm{K}_{2} \mathrm{Cr}_{2} \mathrm{O}_{7}\right)$ method (Walkley and Black 1934). The soil $\mathrm{pH}$ and water holding capacity of TAS are 5 and $49 \%$, respectively.

\section{Higher plant growth test}

To provide conditions for the development of plants, thirty five days before sowing, the $\mathrm{pH}$ of natural soils was adjusted to approximately 6.0 and the base saturation was increased to $50 \%$, by the application of $\mathrm{CaCO}_{3}$ and $\mathrm{MgCO}_{3}$ in a 3:1 molar ratio, as recommended by Alvarez and Ribeiro (1999). Fifteen days before sowing, the soils were fertilized considering the critical levels of nutrients (Alvarez and Ribeiro 1999) and minimum levels of fertilization for plants in pots (Malavolta 1980). Both procedures were performed to avoid reductions in plant growth due to the lack of nutrients in the test substrate, which could mask toxic effects provoked by the presence of the test substance in the soil. A nutrient solution composed of $200 \mathrm{mg} \mathrm{P} \mathrm{kg}{ }^{-1}$, $5 \mathrm{mg} \mathrm{Zn} \mathrm{kg}^{-1}, 1.5 \mathrm{mg} \mathrm{Cu} \mathrm{kg}^{-1}, 1 \mathrm{mg} \mathrm{B} \mathrm{kg}{ }^{-1}$, and $3 \mathrm{mg} \mathrm{Mn}$ $\mathrm{kg}^{-1}$ prepared using analytical-grade ammonium dihydrogen phosphate, Zn-sulfate, boric acid, and Mn-sulfate was mixed in the soils. In both incubation periods and throughout the higher plant growth test, the soil moisture was kept at $60 \%$ of the water holding capacity.

The fertilized soils were air-dried immediately before receiving treatments. The same concentrations of $\mathrm{AcPb}$ and AcK were tested in both soils, comprising a gradient of increasing concentrations of $\mathrm{AcPb}$ composed of $0,78,157$, $314,628,1256,2512,5024 \mathrm{mg} \mathrm{Pb}\left(\mathrm{CH}_{3} \mathrm{COO}\right)_{2} .3 \mathrm{H}_{2} \mathrm{O} \mathrm{kg}$ and a $\mathrm{Pb}$-free acetate control (AcK; $5320 \mathrm{mg} \mathrm{CH}_{3} \mathrm{CO}_{2} \mathrm{~K}$ $\mathrm{kg}^{-1}$ ). The $\mathrm{AcPb}$ concentrations were defined following a multiplying factor of two and were prepared by the addition of different volumes of a stock solution of $91.5 \mathrm{~g} \mathrm{AcPb} \mathrm{L}^{-1}$ prepared in distilled water. The acetate concentration in the AcK control was used to have a treatment free of $\mathrm{Pb}$ but with an acetate concentration equivalent to the acetate concentration present in the $5024 \mathrm{mg} \mathrm{AcPb} \mathrm{kg}{ }^{-1}$ treatment (the highest $\mathrm{AcPb}$ concentration tested). The AcK control was used in the tests to evaluate the influence of the acetate itself in the final toxicity.

Higher plant growth tests using Zea mays (maize) and Phaseolus vulgaris cv. Carioquinha (common bean) were performed following ISO 11269-2 (ISO-International Organizations for Standardization 2005). These species were selected due to their relevance as staple crops. Each replicate corresponded to one pot $(110 \mathrm{~mm}$ height, $120 \mathrm{~mm}$ diameter) containing $600 \mathrm{~g}$ of soil (dry weight equivalent; DW). Ten seeds were sown in each replicate up to $24 \mathrm{~h}$ after the soil spiking and the correction of soil moisture to $60 \%$ of its water holding capacity.

Four replicates were used per treatment and plant species. Plant tests were carried out in a growth chamber at $25 \pm 2{ }^{\circ} \mathrm{C}$ with a photoperiod of $16: 8 \mathrm{~h}$ (light: dark), using a light intensity of $8.000 \pm 2.000$ lux in the light periods. Soil moisture was reestablished by capillarity (each test pot was connected to an individual container filled with distilled water through a rope).

The test started after the emergence of $50 \%$ of the seeds in the control replicates. In all treatments, surplus plants were trimmed to leave only five plants per pot. During the experiment, the test replicates were randomly distributed within the growth chamber. The $\mathrm{N}$ and $\mathrm{K}$ nutrients were applied on the 7th and 14th days after starting the test on the soil surface, with a total of $300 \mathrm{mg} \mathrm{N} \mathrm{kg}^{-1}$ applied as urea and $150 \mathrm{mg} \mathrm{K} \mathrm{kg}^{-1}$ as a nutrient solution of analytical-grade $\mathrm{KCl}$. After 21 days of the beginning of the test, plants were harvested at the stem base in all replicates. Then, the harvested plants were dried at $75^{\circ} \mathrm{C}$ for $72 \mathrm{~h}$ and weighted to determine the shoot dry matter (SDM).

\section{Ecotoxicological tests with soil invertebrates}

Laboratory reproduction tests were performed using the three soils (Oxisol, Inceptisol, and TAS) without $\mathrm{pH}$ adjustment (Table 1) and the springtails Folsomia candida, the earthworms Eisenia andrei, and the enchytraeids, Enchytraeus crypticus as test organisms and following the ISO guidelines 11267 (ISO-International Organizations for Standardization 1999), 11268-2 (ISO-International Organizations for Standardization 1998) and 16387 (ISOInternational Organizations for Standardization 2004), respectively.

The organisms used in the tests were grown in the laboratory, at a temperature of $25 \pm 2{ }^{\circ} \mathrm{C}$ and a photoperiod of 16:8 h light: dark. Springtails were kept in plastic boxes $(11 \mathrm{~cm}$ diameter and $4 \mathrm{~cm}$ height) containing a mixture of plaster of Paris and activated charcoal in a ratio of 11:1 (w:w), being fed weekly with dry granulated yeast. Earthworms were kept in plastic boxes $(36 \mathrm{~cm}$ length, $22 \mathrm{~cm}$ 
width, and $11 \mathrm{~cm}$ height) with a substrate containing a mixture of horse dung, previously defaunated through two freeze-thawing cycles of $48 \mathrm{~h}$ at $-20^{\circ} \mathrm{C}$ followed by $48 \mathrm{~h}$ at $25^{\circ} \mathrm{C}$, and peat in a proportion of $1: 1, \mathrm{w}-\mathrm{w}$. Moisture was kept between 40 and $60 \%$ of the water holding capacity of the mixture. Earthworms were fed twice a month with one spoon of horse dung. Enchytraeids were kept on Petri dishes (9 cm diameter and $1 \mathrm{~cm}$ height) filled with agar as described by Cesar et al. (2015b) and were fed weekly with finely ground autoclave-sterilized oat.

Natural soils were defaunated by two freeze-thawing cycles $\left(48 \mathrm{~h}\right.$ at $-20^{\circ} \mathrm{C}$ followed by $48 \mathrm{~h}$ at $25^{\circ} \mathrm{C}$ ), after which, their microbial community was restored by inoculation of $100 \mathrm{~mL}$ of elutriates per $\mathrm{kg}$ of fresh soil. The elutriates were obtained by stirring fresh and nondefaunated soil samples with water in a ratio proportion of 1:10 (w:v) for $30 \mathrm{~min}$. After this procedure, both soils were stored for 10 days at room temperature in the dark before being spiked with $\mathrm{AcPb}$ or $\mathrm{AcK}$ in the laboratory for testing.

In each laboratory test, the invertebrate species were exposed to a concentration gradient composed of the following increasing concentrations of $\mathrm{AcPb}: 0,314,628$, 1256, 2512, 5024, 10048, $20095 \mathrm{mg} \mathrm{AcPb} \mathrm{kg}{ }^{-1}$ soil dry weight and a $\mathrm{Pb}$-free acetate control with $12,121 \mathrm{mg}$ of $\mathrm{CH}_{3} \mathrm{CO}_{2} \mathrm{~K} \mathrm{~kg}^{-1}$. The concentrations selected for the reproduction tests were based on data from the available literature concerning the toxicity of $\mathrm{Pb}$ to Eisenia fetida (Neuhauser et al. 1985; Spurgeon et al. 1994; Davies et al. 2002, 2003), Folsomia candida (Sandifer and Hopkin 1997; Jie et al. 2009) and Enchytraeus albidus (Lock and Janssen 2003) using different lead salts as a source of contamination. For each treatment, soil aliquots were spiked through the addition of different volumes of a stock solution of 130.6 $\mathrm{g} \mathrm{AcPb} \mathrm{L}^{-1}$ or $135.2 \mathrm{~g} \mathrm{AcK} \mathrm{L}^{-1}$ (prepared with water) and water to obtain the desired concentration and soil moisture of $50 \%$ of its maximum water holding capacity. Soil spiking was performed immediately before the beginning of the laboratory tests. Tests with invertebrate species were performed at $25 \pm 2{ }^{\circ} \mathrm{C}$ and under a photoperiod of 16:8 h (light: dark).

In the reproduction tests with $F$. candida, ten synchronized organisms 10-12 days old were used per replicate in a total of five replicates per treatment. Each replicate consisted of cylindrical plastic containers $(7 \mathrm{~cm}$ diameter and $6 \mathrm{~cm}$ height) with $30 \mathrm{~g}$ of soil (fresh weight). During the experiment, the test organisms were fed by adding ca. $2 \mathrm{mg}$ of dry granulated yeast in the test container at the beginning of the test and after 14 days of exposure. Once a week, the vessels were opened to allow aeration and to restore water losses by the addition of few drops of distilled water. After 28 days the test was finished and the content of each vessel was transferred to a larger container and filled with water.
Drops of blue ink were added and the soil was gently stirred in the bottom of the vessels. Then, the water surface was photographed, and the number of juveniles and living adults was determined using the software ImageJ. Soil moisture and $\mathrm{pH}$ were measured at the beginning of the experiment in all treatments. An additional replicate without organisms was prepared per treatment for soil $\mathrm{pH}$ and moisture determinations at the end of the experiment.

In the reproduction tests with $E$. andrei, four replicates were prepared per treatment. Each replicate consisted of one plastic pot (11 cm diameter and $12 \mathrm{~cm}$ height) containing $500 \mathrm{~g}$ of soil (dry weight). Ten earthworms with fully developed clitellum, more than two months old, previously rinsed, and $386 \pm 74 \mathrm{mg}$ of individual weight (average \pm standard deviation; $n=1080$ ) were introduced in each replicate. Each test container was covered by a transparent lid with small holes to allow aeration. These covers were used to reduce water losses by evaporation and prevent the organisms from escaping. Fifteen grams of horse dung, previously defaunated, were added to each pot as food at the beginning of the experiment and at the 14th and 28th days of the test. On the 28th day, living adults were removed, counted, and weighted to determine the number of survivals and the percentage of initial biomass. On the 56th day of the experiment, the test ended and the experimental units were placed into a water bath at $50-60{ }^{\circ} \mathrm{C}$ to force the juveniles to raise in the soil surface, allowing to determine the number of juveniles in each test container.

In the reproduction tests with E. crypticus, replicates containing ten individuals of similar size and developed clitellum were used for each treatment. Four replicates were prepared per treatment, except for control $\left(0 \mathrm{mg} \mathrm{AcPb} \mathrm{kg}^{-1}\right)$ in which eight replicates were used. Each replicate consisted of cylindrical glass vessels (6 cm diameter and $9 \mathrm{~cm}$ height) with $20 \mathrm{~g}$ of soil (dry weight equivalent). Finely ground oats, $2 \mathrm{mg}$ per replicate, were provided as food at the $0,7 \mathrm{th}$, 14 th, and 21 st days of the test. Once a week, test containers were opened to allow aeration, and water losses were restored whenever weight losses were higher than $2 \%$. After a test period of 28 days, the organisms were killed by adding a few milliliters of an $80 \%$ ethanol solution in the replicates and stained with a few drops of a Rose Bengal solution ( $1 \%$ in ethanol). After $12 \mathrm{~h}$, the soil was rinsed in a $0.25 \mathrm{~mm}$-sieve, enchytraeids were transferred to a Petri dish and the total number of organisms was determined using a binocular magnifying glass (Chelinho et al. 2014). The number of adults could not be determined as the size of juveniles did not allow us to distinguish the surviving adults from some juveniles at the end of the test. Since the number of surviving adults (10 at most) was considerably lower than the number of juveniles at the end of the test, the total number of juveniles was determined by counting all Enchytraeids at the end of the test in each replicate. As for 
Table 2 Lead acetate $(\mathrm{AcPb})$ and lead $(\mathrm{Pb})$ nominal concentrations and $\mathrm{Pb}$ actual concentrations (mean \pm standard deviation; $n=3$; expressed in $\mathrm{mg} \mathrm{kg}^{-1}$ ) in treatments of Oxisol and Inceptisol (and respective percentages of $\mathrm{Pb}$ nominal concentrations for each soil) used in the laboratory higher plant growth tests

\begin{tabular}{|c|c|c|c|c|c|c|}
\hline \multirow[t]{2}{*}{ Treatment } & \multirow[t]{2}{*}{$\mathrm{AcPb}$ nominal } & \multirow[t]{2}{*}{$\mathrm{Pb}$ nominal } & \multicolumn{2}{|l|}{ Oxisol } & \multicolumn{2}{|l|}{ Inceptisol } \\
\hline & & & $\mathrm{Pb}$ actual & $\%$ of $\mathrm{Pb}$ nominal & $\mathrm{Pb}$ actual & $\%$ of $\mathrm{Pb}$ nominal \\
\hline $\mathrm{C} 0$ & 0 & 0 & $4.1 \pm 0.3$ & - & $9.9 \pm 0.4$ & - \\
\hline $\mathrm{C} 1$ & 78 & 50 & $49 \pm 2.5$ & 98 & $55 \pm 1.5$ & 110 \\
\hline $\mathrm{C} 2$ & 157 & 100 & $119 \pm 1.7$ & 119 & $92 \pm 2.5$ & 92 \\
\hline $\mathrm{C} 3$ & 314 & 200 & $198 \pm 2.6$ & 99 & $188 \pm 4.0$ & 94 \\
\hline $\mathrm{C} 4$ & 628 & 400 & $412 \pm 1.5$ & 103 & $400 \pm 3.1$ & 100 \\
\hline C5 & 1256 & 800 & $796 \pm 1.0$ & 99.5 & $798 \pm 2.1$ & 99.8 \\
\hline C6 & 2512 & 1600 & $1599 \pm 1.0$ & 99.9 & $1591 \pm 3.0$ & 99.4 \\
\hline C7 & 5024 & 3200 & $3225 \pm 0.6$ & 100.8 & $3187 \pm 4.5$ & 99.6 \\
\hline AcK & $5320^{a}$ & 0 & $6.4 \pm 0.2$ & - & $8.1 \pm 0.4$ & - \\
\hline
\end{tabular}

${ }^{\text {a }}$ Potassium acetate nominal concentration (in $\mathrm{mg} \mathrm{kg}^{-1}$ )
Collembola reproduction tests, soil $\mathrm{pH}$ and moisture were determined at the beginning of the test and an additional replicate without organisms was prepared per each treatment for soil $\mathrm{pH}$ and moisture determinations at the end of the experiment.

\section{Chemical analyses}

A composite sample was collected per treatment to determine $\mathrm{Pb}$ concentration, immediately after soil spiking with $\mathrm{AcPb}$ and $\mathrm{AcK}$ in all tests. Lead extraction was performed according to the USEPA 3051A method (USEPA 2007). Lead was determined by air-acetylene flame atomic absorption spectrophotometry, with detection and quantification limits of the method of 0.3 and $0.9 \mathrm{mg} \mathrm{L}^{-1}$, respectively (Penha et al. 2017). The reference material BCR 142 R-light sandy soil (Community Bureau of Reference, Brussels) was used to verify the accuracy of $\mathrm{Pb}$ measurements. The recovery of $\mathrm{Pb}$ ranged between 90 and $110 \%$ of the reference material.

\section{Statistical analyses}

The shoot dry matter (SDM) of plants, the percentage of initial biomass of surviving earthworms, and the reproductive output of earthworms, collembolans, and enchytraeids were statistically analyzed by one-way ANOVAs followed by Dunnett's post hoc test (Dunnett 1955) to test for significance of the difference between the control and the $\mathrm{AcPb}$ contaminated soils and $\mathrm{AcK}$ control in each test. When the ANOVA assumptions of normality (Kolmogorov-Smirnov test for $\mathrm{p}>0.05$ ) and homoscedasticity (Bartlett test (Bartlett 1937), for $\mathrm{p}>0.05$ ) were violated, Kruskal-Wallis ANOVA by Ranks (Kruskal and Wallis 1952) followed by a multiple comparison test was used.

The effective concentrations- $-\mathrm{EC}_{20}$ and $\mathrm{EC}_{50}$ valuesand the respective $95 \%$ confidence intervals were calculated to estimate the concentrations that produce 20 and $50 \%$ change in the response (i.e., effects) on SDM in plants and reproduction of earthworms, collembolans, and enchytraeids. These values were estimated through non-linear regressions, using an exponential, Gompertz, or Logistic model (EC 2007). The model selected was the one that presented the highest determination coefficient $\left(\mathrm{R}^{2}\right)$ and the smallest $95 \%$ confidence interval. Non-linear regressions followed the method Levenberg-Marquardt and the assumptions of non-linear regressions were checked by the analysis of the normality of the residuals via $\mathrm{Q}-\mathrm{Q}$ plots.

One-way ANOVAs and non-linear regressions were performed using the Statistica 7.0 software (Statsoft INC 2004). Significant differences between $\mathrm{EC}_{50}$ values of different test soils for the same species or between $\mathrm{EC}_{50}$ values of different species in the same soil were determined using a generalized likelihood ratio test.

\section{Results}

Lead concentrations in the soils of the control treatment (without the addition of $\mathrm{Pb}$ ) were $4.1,9.9$, and $7.6 \mathrm{mg} \mathrm{kg}^{-1}$ in the Oxisol, Inceptisol, and TAS, respectively. These concentrations for natural soils (Oxisol and Inceptisol) are within the range of values considered normal for $\mathrm{Pb}$ background in the area (Guevara et al. 2018). The concentrations of $\mathrm{Pb}$ in the $\mathrm{AcPb}$ treatments in the Oxisol, Inceptisol, and TAS represented the added $\mathrm{Pb}$ concentration (Tables 2 and 3). Thus, chemical measurements confirmed that the test organisms (plants and soil invertebrates) were exposed to a gradient of increasing $\mathrm{Pb}$ concentrations. Since the actual concentrations showed a percentage of nominal concentrations close to $100 \%$, the effective concentrations $\left(\mathrm{EC}_{50}\right.$ and $\mathrm{EC}_{20}$ ) were estimated based on the nominal concentrations of $\mathrm{AcPb}$.

The AcK treatments were toxic to all test species (plant, springtails, enchytraeids, and earthworms), considering the 
Table 3 Lead acetate $(\mathrm{AcPb})$ and lead $(\mathrm{Pb})$ nominal concentrations and $\mathrm{Pb}$ actual concentrations (mean \pm standard deviation; $n=3$; expressed in $\mathrm{mg} \mathrm{kg}^{-1}$ ) in treatments of Oxisol, Inceptisol and Tropical Artificial Soil (TAS; and respective percentages of $\mathrm{Pb}$ nominal concentrations for each soil) used in the laboratory reproduction tests with soil invertebrates

\begin{tabular}{|c|c|c|c|c|c|c|c|c|}
\hline \multirow[t]{2}{*}{ Treatment } & \multirow{2}{*}{$\begin{array}{l}\mathrm{AcPb} \\
\text { nominal }\end{array}$} & \multirow[t]{2}{*}{$\mathrm{Pb}$ nominal } & \multicolumn{2}{|l|}{ Oxisol } & \multicolumn{2}{|l|}{ Inceptisol } & \multicolumn{2}{|l|}{ TAS } \\
\hline & & & $\mathrm{Pb}$ actual & $\begin{array}{l}\% \text { of } \mathrm{Pb} \\
\text { nominal }\end{array}$ & $\mathrm{Pb}$ actual & $\begin{array}{l}\% \text { of } \mathrm{Pb} \\
\text { nominal }\end{array}$ & $\mathrm{Pb}$ actual & $\begin{array}{l}\% \text { of } \mathrm{Pb} \\
\text { nominal }\end{array}$ \\
\hline $\mathrm{C} 0$ & 0 & 0 & $4.1 \pm 0.2$ & - & $9.9 \pm 0.3$ & - & $7.6 \pm 0.3$ & - \\
\hline $\mathrm{C} 1$ & 314 & 200 & $193 \pm 3.1$ & 96.5 & $191 \pm 2.1$ & 95.5 & $186 \pm 2.6$ & 93 \\
\hline $\mathrm{C} 2$ & 628 & 400 & $395 \pm 1.5$ & 98.8 & $397 \pm 2.6$ & 99.3 & $392 \pm 2.1$ & 98 \\
\hline C3 & 1256 & 800 & $789 \pm 2.1$ & 98.6 & $798 \pm 3.5$ & 99.8 & $788 \pm 4.4$ & 98.5 \\
\hline $\mathrm{C} 4$ & 2512 & 1600 & $1598 \pm 3.0$ & 99.9 & $1593 \pm 3.1$ & 99.6 & $1596 \pm 2.1$ & 99.8 \\
\hline C5 & 5024 & 3200 & $3200 \pm 1.0$ & 100 & $3198 \pm 1.5$ & 99.9 & $3197 \pm 4.2$ & 99.9 \\
\hline C6 & 10,048 & 6400 & $6400 \pm 1.7$ & 100 & $6404 \pm 2.0$ & 100.1 & $6437 \pm 3.8$ & 100.6 \\
\hline $\mathrm{C} 7$ & 20,095 & 12,800 & $12,800 \pm 1.2$ & 100 & $12,790 \pm 5.6$ & 99.9 & $12,807 \pm 3.6$ & 100.1 \\
\hline $\mathrm{AcK}$ & $12,121^{\mathrm{a}}$ & 0 & $5.1 \pm 0.3$ & - & $9.1 \pm 0.3$ & - & $10.3 \pm 0.3$ & - \\
\hline
\end{tabular}

${ }^{a}$ Potassium acetate (AcK) nominal concentration (in $\mathrm{mg} \mathrm{kg}^{-1}$ )

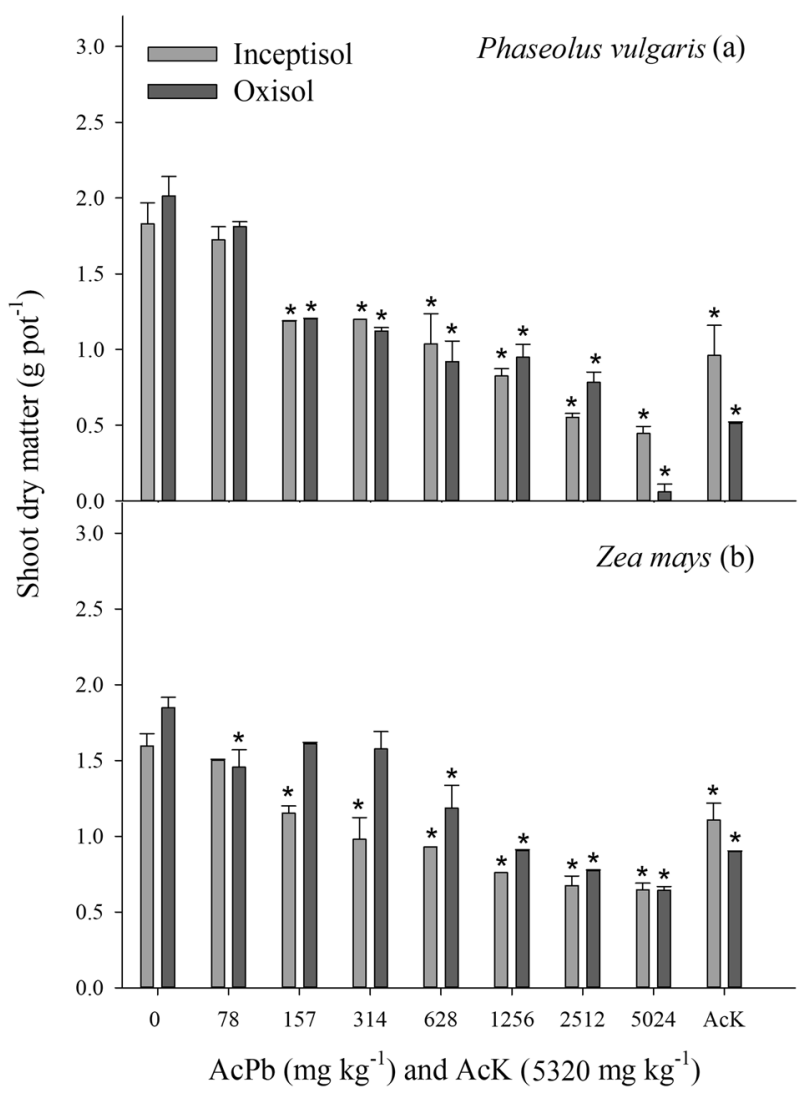

Fig. 1 Shoot dry matter production (average \pm standard deviation, $n=4$ ) of Phaseolus vulgaris (a) and Zea mays (b) when exposed to an Oxisol and an Inceptisol spiked with increasing concentrations of lead acetate $(\mathrm{AcPb})$ or potassium acetate (in a concentration of $5320 \mathrm{mg}$ $\mathrm{kg}^{-1}$; AcK) in a higher plant growth test. *-Shoot dry matter significantly different from respective control $\left(0 \mathrm{mg} \mathrm{kg}^{-1}\right.$; Dunnett's test, $p \leq 0.05$ )

Oxisol and Inceptisol for SDM (Fig. 1) and Oxisol, Inceptisol, and TAS for the number of juveniles, and the initial percentage of biomass (Figs. 2 and 3). As expected, $\mathrm{Pb}$ chemical measurements in the Oxisol, Inceptisol, and TAS showed that AcK treatments had $\mathrm{Pb}$ concentrations $\left(\mathrm{mg} \mathrm{kg}^{-1}\right)$ similar to that of control treatments without application of $\mathrm{Pb}$, for the tests with plants (Oxisol-6.4 \pm 0.2 and Inceptisol $-8.1 \pm 0.4$ ) and soil invertebrates (Oxisol $-5.1 \pm 0.3$, Inceptisol-9.1 \pm 0.3 and TAS $-10.3 \pm 0.3$ ).

In the higher plant growth tests, all validity criteria defined in the abovementioned protocols were met. The percentage of emergence in the control treatment was 80 and $81 \%$ for $Z$. mays and 81 and $83 \%$ for $P$. vulgaris in the Oxisol and Inceptisol, respectively. For $P$. vulgaris, SDM was significantly affected in both natural soils (Oxisol and Inceptisol) by concentrations higher than or equal to $157 \mathrm{mg}$ $\mathrm{AcPb} \mathrm{kg}{ }^{-1}$ and in AcK treatment (Fig. 1a). In the Inceptisol, concentrations greater than or equal to $157 \mathrm{mg} \mathrm{AcPb} \mathrm{kg}^{-1}$ significantly affected $Z$. mays SDM. The same was observed for AcK at $3200 \mathrm{mg} \mathrm{kg}^{-1}$ (Fig. 1b). It was observed a significant effect on SDM when Z. mays plants were grown in the Oxisol with concentrations higher than or equal to $628 \mathrm{mg} \mathrm{AcPb} \mathrm{kg}^{-1}(628,1256,2512$, and $5024 \mathrm{mg}$ $\mathrm{kg}^{-1}$ ), except for the $78 \mathrm{mg} \mathrm{AcPb} \mathrm{kg}{ }^{-1}$, which also had a significant effect. A significant decrease was also observed in the AcK treatment (Fig. 1b).

In the laboratory tests with soil invertebrates, all validity criteria were met. In the control treatment, the percentage of adult survival of E. andrei and $F$. candida were 98, 100, 100 and 84, 82, 82\% in the Oxisol, the Inceptisol, and the TAS, respectively. The mean of juveniles (and associated coefficient of variation) produced in control treatment in the Oxisol, the Inceptisol, and the TAS were, respectively, 41 (20\%), 61 (30\%), and 44 (10\%) for E. andrei; 412 (24\%), $713(28 \%)$, and $775(29 \%)$ for $F$. candida; $573(37 \%), 1228$ (17\%), and 1204 (15\%) for E. crypticus.

Effects on $F$. candida reproduction were observed in concentrations higher than or equal to $2512 \mathrm{mg} \mathrm{kg}^{-1}$ in natural soils, and higher than or equal to $5024 \mathrm{mg} \mathrm{AcPb} \mathrm{kg}^{-1}$ in the TAS soil (Fig. 2a). The exception was the $314 \mathrm{mg} \mathrm{kg}^{-1}$ concentration in the Inceptisol in which significant effects 


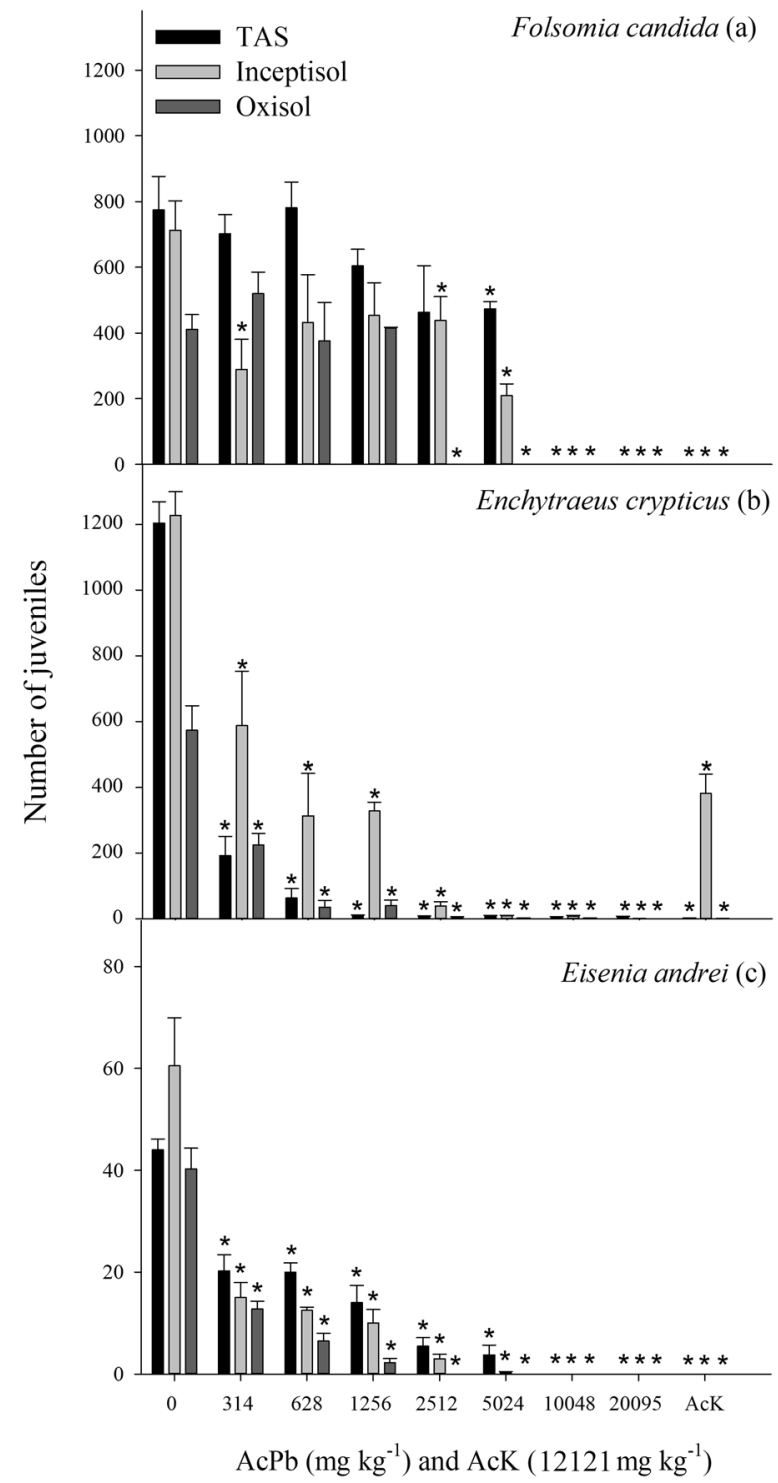

Fig. 2 Number of juveniles (average \pm standard deviation, $n=4-5$ ) of Folsomia candida (a), Enchytraeus crypticus (b), and Eisenia andrei (c) when exposed to an Oxisol, an Inceptisol, and a Tropical Artificial Soil (TAS) spiked with increasing concentrations of lead acetate $(\mathrm{AcPb})$ or potassium acetate (in a concentration of $12121 \mathrm{mg} \mathrm{kg}^{-1}$; AcK) in laboratory reproduction tests. *-Number of juveniles significantly different compared from respective control $\left(0 \mathrm{mg} \mathrm{kg}^{-1}\right.$; Dunnett's test, $p \leq 0.05$ )

were observed (Fig. 2a). However, this decrease was not consistent with the reproductive pattern observed over the concentration gradient used in the test. Living adults of $F$. candida were not observed in concentrations higher than or equal to $2512 \mathrm{mg} \mathrm{AcPb} \mathrm{kg}^{-1}$ in both the Oxisol and the Inceptisol, and in the TAS in concentrations higher than $10048 \mathrm{mg} \mathrm{AcPb} \mathrm{kg}{ }^{-1}$ (Fig. 2a).

For E. crypticus and E. andrei, effects on reproduction were observed in concentrations greater than or equal to $314 \mathrm{mg} \mathrm{AcPb} \mathrm{kg}{ }^{-1}$ (Fig. 2b, c).

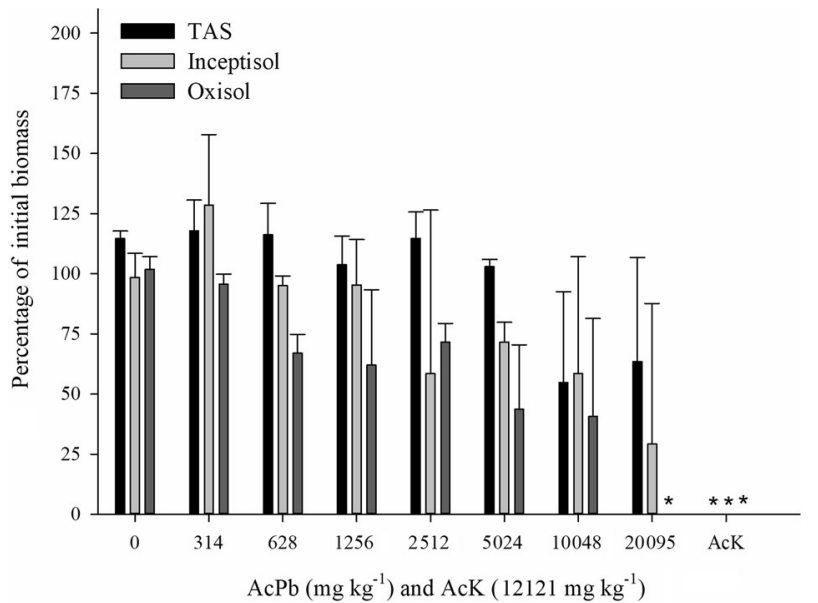

Fig. 3 Percentage of the initial biomass (average \pm standard deviation, $n=4$ ) of surviving adults of $E$. andrei after being exposed to an Oxisol, an Inceptisol, and a Tropical Artificial Soil (TAS) spiked with increasing concentrations of $\mathrm{Pb}$ acetate $(\mathrm{AcPb})$ or potassium acetate $(\mathrm{AcK})$ in laboratory reproduction tests. *-Percentage significantly different from the respective control (Dunnett's test, $p \leq 0.05$ )

Effects of $\mathrm{AcPb}$ on $E$. andrei initial biomass were observed only for the highest $\mathrm{AcPb}\left(20095 \mathrm{mg} \mathrm{AcPb} \mathrm{kg}{ }^{-1}\right.$ ) concentration in the Oxisol (Fig. 3).

The $\mathrm{EC}_{50}$ values for $\mathrm{AcPb}$ calculated for the five test species are presented in Table 4 . The monocotyledonous $Z$. mays showed a sensitivity significantly lower than that of the dicotyledonous $P$. vulgaris in the Oxisol. In the Inceptisol, the average $\mathrm{EC}_{50}$ values for $P$. vulgaris were also lower; however, the confidence interval does not confirm the difference between the $\mathrm{EC}_{50}$ values of $Z$. mays and $P$. vulgaris. For the three species of soil invertebrates, in general, the sensitivity decreased in the following order: $E$. crypticus $>$ E. andrei $>$ F. candida.

\section{Discussion}

The toxicity of $\mathrm{AcPb}$ changed according to soil type and composition. An increased soil $\mathrm{pH}$ can contribute to a reduced concentration of $\mathrm{Pb}$ in soil solution, owing to the lower solubility of $\mathrm{AcPb}$ (Harter 1983; Alloway 2013). Conversely, the reduction of soil $\mathrm{pH}$ following the application of $\mathrm{AcPb}$ in the natural tropical soils can be explained by the strong affinity between $\mathrm{Pb}^{2+}$ and $\mathrm{Fe}$ oxides, namely hematite (Pierangeli et al. 2001a, b), on which the specific adsorption of $\mathrm{Pb}^{2+}$ may release $\mathrm{H}^{+}$and cause soil acidification. The influence of $\mathrm{pH}$ on $\mathrm{Pb}$ toxicity and availability was reported by other authors (Bur et al. 2012; Ardestani et al. 2014; Romero-Freire et al. 2015). The pH reduction following the $\mathrm{AcPb}$ addition was not observed in the TAS most probably because this soil is not rich in Fe oxides. Thus, the attributes of natural soils provided greater 
Table $4 \mathrm{EC}_{50}$ and $\mathrm{EC}_{20}$ values (and respective $95 \%$ confidence intervals) for the effects on growth of $Z$. mays and $P$. vulgaris and reproduction of E. andrei, F. candida, and E. crypticus exposed to an Oxisol, an Inceptisol, and a Tropical Artificial Soil (TAS) spiked with increasing concentrations of $\mathrm{Pb}$ acetate $(\mathrm{AcPb})$. Values are expressed in $\mathrm{mg}$ of $\mathrm{AcPb} \mathrm{kg}{ }^{-1}$ of soil

\begin{tabular}{lllc}
\hline Species & Soil & $\mathrm{EC}_{20}$ & $\mathrm{EC}_{50}$ \\
& & $-------\mathrm{mg} \mathrm{kg}^{-1}-------$ \\
\hline E. andrei & Oxisol & $68.8(5-132)$ & $141.9(48-235)$ \\
& Inceptisol & $\mathrm{NV}^{\mathrm{a}}$ & $177.4(113-245)$ \\
& TAS & $73.6(10-138)$ & $370.5(209-534)$ \\
F. candida & Oxisol & $\mathrm{NV}$ & $1835(36-3633)$ \\
& Inceptisol & $\mathrm{NV}$ & $3606(1129-6089)$ \\
& TAS & $2050.3(651-3451)$ & $4601.5(2879-6325)$ \\
E. crypticus & Oxisol & $\mathrm{NV}$ & $52.3(30-75)$ \\
& Inceptisol & $\mathrm{NV}$ & $72.2(35-109)$ \\
& TAS & $\mathrm{NV}$ & $29.8(22-38)$ \\
Z. mays & Oxisol & $1078.5(568-1587)$ & $1527.5(893-2162)$ \\
& Inceptisol & $\mathrm{NV}$ & $1229.3(490-1967)$ \\
P. vulgaris & Oxisol & $\mathrm{NV}$ & $560.5(251-871)$ \\
& Inceptisol & $100.5(9-191)$ & $802.2(413-1192)$ \\
\hline
\end{tabular}

${ }^{\mathrm{a}} \mathrm{NV}$ - data not validated by nonlinear regression models $(p<0.05)$

sensitivity to soil invertebrates exposed to $\mathrm{AcPb}$. Moreover, the results obtained evidenced that the use of TAS could underestimate the toxicity of the test substance, which seems to make the TAS less suitable to assess toxicity of $\mathrm{AcPb}$. This fact gives strength to the use of local natural soils in the assessment of chemicals toxicity, at least in tropical regions. Despite that, the use of an artificial standard soil (i.e. TAS) is still advisable (even when not representing a worst-case scenario) to allow the comparison of toxicity data between laboratories.

Besides pH (Pierangeli et al. 2001a), Pb availability in soils is affected by specific adsorption to soil solid phases (Pierangeli et al. 2001b), precipitation of poorly soluble compounds, and formation of relatively stable complexes and chelates with soil organic matter. Lead sorption is also dependent on the distribution of soil particle-size fractions, owing to their varying reactivity and specific surface area (Romero-Freire et al. 2015; Zhang et al. 2019b). This can explain the increased toxicity observed in the Oxisol compared with the Inceptisol, as the latter has increased clay and organic matter contents relatively to the Oxisol, and these attributes are related to greater $\mathrm{Pb}$ retention capacity.

According to Zhang et al. (2019b), soil pH is the main predictive factor for $\mathrm{Pb}$ toxicity to enchytraeid reproduction. In that study, E. crypticus individuals were exposed for 21 days to the natural standard soils Lufa 2.1, Lufa 2.2, Lufa 2.3, Lufa 2.4, and Lufa $5 \mathrm{M}$ (Speyer, Germany) and a grassland soil, all contaminated with $\mathrm{Pb}\left(\mathrm{NO}_{3}\right)_{2}$ (Zhang et al. $2019 b)$. The $\mathrm{EC}_{50}$ values for $E$. crypticus reproduction ranged between 81.4 and $1008 \mathrm{mg}$ of $\mathrm{Pb} \mathrm{kg}^{-1}$. The lowest value was observed for the Lufa 2.1 soil $(\mathrm{OM}=1.3 \%$; $\mathrm{CEC}$ $\left.=2.2 \mathrm{cmol}_{\mathrm{c}} \mathrm{kg}^{-1} ; \mathrm{pH}=4.8\right)$ and the highest value for the LUFA $5 \mathrm{M}$ soil $\left(\mathrm{OM}=2.6 \% ; \mathrm{CEC}=10.1 \mathrm{cmol}_{\mathrm{c}} \mathrm{kg}^{-1} ; \mathrm{pH}\right.$ $=6.9$ ). The conclusion of Zhang et al. (2019b) was attributed after finding similar $\mathrm{EC}_{50}$ values in soils with different properties (CEC, OM content, and clay content), but with approximate values of $\mathrm{pH}$ (LUFA 2.4, LUFA $5 \mathrm{M}$, and grassland soil), indicating that $\mathrm{pH}$ was the main factor describing the toxicity of $\mathrm{Pb}$ on enchytraeid reproduction. Along with $\mathrm{pH}, \mathrm{CEC}$ and $\mathrm{Ca}$ concentration in porewater were identified as the factors determining $\mathrm{EC}_{50}$ and $\mathrm{EC}_{10}$ based on total $\mathrm{Pb}$ concentration (Zhang et al. 2019b). The three soils used in the present study presented $\mathrm{pH}$ around 6.0 after the application of carbonates and the $\mathrm{EC}_{50}$ values observed in the natural soils (Oxisol $33.3 \mathrm{mg} \mathrm{Pb} \mathrm{kg}^{-1}$ and Inceptisol $46 \mathrm{mg} \mathrm{Pb} \mathrm{kg}^{-1}$ ) for E. crypticus reproduction were lower for the Oxisol $\left(\mathrm{OM}=1.6 \%\right.$; $\mathrm{CEC}=5.0 \mathrm{cmol}_{\mathrm{c}}$ $\left.\mathrm{kg}^{-1}\right)$ than for the Inceptisol $(\mathrm{OM}=2.9 \%$; $\mathrm{CEC}=6.1$ $\mathrm{cmol}_{\mathrm{c}} \mathrm{kg}^{-1}$ ), indicating that the difference of toxicity is probably also related to differences in OM content. Literature data support the high influence of $\mathrm{OM}$ content on $\mathrm{EC}_{50}$ values (Fig. S1).

The organic matter content in the TAS (5.0\%) may have contributed to diminishing the toxic effects of $\mathrm{AcPb}$ on soil organisms. However, this was not observed for E. crypticus, with an $\mathrm{EC}_{50}$ value of $19 \mathrm{mg} \mathrm{Pb} \mathrm{kg}^{-1}$ being the lowest average EC50 value for the species (plants and soil invertebrates). The different $\mathrm{EC}_{50}$ values for E. crypticus reproduction in both natural soils (Oxisol and Inceptisol) may be also related to $\mathrm{Ca}^{2+}$ concentrations in each soil. It is known that $\mathrm{Ca}^{2+}$ outruns $\mathrm{Pb}^{2+}$ for specific absorption sites in living organisms (Zhang et al. 2019b). This may have contributed to the reduced toxicity of $\mathrm{AcPb}$ in the Inceptisol, as it presented a higher $\mathrm{EC}_{50}$ value and higher $\mathrm{Ca}^{2+}$ concentration compared with the Oxisol.

The survey of $\mathrm{EC}_{50}$ data (Table 5) in the literature for $\mathrm{Pb}$ shows how soil chemistry ( $\mathrm{pH}, \mathrm{OM}$, and $\mathrm{Ca}$ ), $\mathrm{Pb}$ salt used, invertebrate, and plant species influence $\mathrm{Pb}$ toxicity (Cheyns et al. 2012; Smolders et al. 2015). In a study with springtails (F. candida) exposed to an artificial soil (10\% Sphagnum peat, $20 \%$ kaolinite clay, and $70 \%$ quartz sand) contaminated with $\mathrm{Pb}\left(\mathrm{NO}_{3}\right)_{2}$, Menta et al. (2006) did not observe effects from concentrations lower than $500 \mathrm{mg} \mathrm{Pb}$ $\mathrm{kg}^{-1}$, and decreased reproduction (16\%) was only observed at the $1000 \mathrm{mg} \mathrm{kg}^{-1}$ concentration. These results are consistent with the present study since significant decreases in reproduction were not observed in $\mathrm{AcPb}$ concentrations lower than $1256 \mathrm{mg} \mathrm{kg}^{-1}$ ( $800 \mathrm{mg} \mathrm{Pb} \mathrm{kg}^{-1}$ ), except for the dose $314 \mathrm{mg} \mathrm{kg}^{-1}$ of $\mathrm{AcPb}\left(200 \mathrm{mg} \mathrm{Pb} \mathrm{kg}{ }^{-1}\right)$ in the Inceptisol. The salt used as a source of contamination may itself influence the performance of the assays. For instance, $\mathrm{Pb}\left(\mathrm{NO}_{3}\right)_{2}$ is more toxic to $F$. candida than $\mathrm{PbCl}_{2}$ (Fountain 
Table $5 \mathrm{EC}_{50}$ values for the effects on growth of plants and reproduction of soil invertebrates. Values are expressed in $\mathrm{mg}$ of Pb $\mathrm{kg}^{-1}$ of soil

\begin{tabular}{|c|c|c|c|c|c|c|c|c|c|}
\hline \multirow[t]{2}{*}{ Site } & \multirow[t]{2}{*}{ Soils } & \multicolumn{4}{|c|}{ Soil properties } & \multirow[t]{2}{*}{ Species } & \multirow[t]{2}{*}{$\mathrm{EC} 50 \mathrm{mg} \mathrm{kg}^{-1}$} & \multirow[t]{2}{*}{$\mathrm{Pb}$ source } & \multirow[t]{2}{*}{ Reference } \\
\hline & & $\mathrm{pH}$ & $\begin{array}{l}\text { CEC } \\
\text { cmolc kg }{ }^{-1}\end{array}$ & $\begin{array}{l}\mathrm{OM} \\
\%\end{array}$ & $\begin{array}{l}\mathrm{OC} \\
\%\end{array}$ & & & & \\
\hline \multirow[t]{3}{*}{ Brazil } & Oxisol & 6.1 & 5.0 & 1.6 & - & \multirow[t]{3}{*}{ E. andrei } & 90 & \multirow{3}{*}{$\mathrm{Pb}$ acetate } & \multirow[t]{3}{*}{ Present study } \\
\hline & Inceptisol & 5.7 & 6.1 & 2.9 & - & & 113 & & \\
\hline & $\mathrm{TAS}^{\mathrm{a}}$ & 6.0 & - & 5.0 & - & & 236 & & \\
\hline Spain & Calcic Luvisol & 7.4 & 14.3 & - & 1.2 & \multirow[t]{4}{*}{ E. fetida } & 480 & \multirow[t]{4}{*}{$\mathrm{Pb}$ chloride } & \multirow[t]{4}{*}{ Smolders et al. (2015) } \\
\hline \multirow[t]{2}{*}{ United Kingdom } & Dystric Luvisol & 6.1 & 26.5 & - & 4.3 & & 2400 & & \\
\hline & & 6.1 & 26.5 & - & 4.3 & & 4530 & & \\
\hline Belgium & Haplic Luvisol & 6.2 & 8.4 & - & 1.0 & & 1710 & & \\
\hline \multirow[t]{6}{*}{ Netherlands } & Lufa $2.1^{\mathrm{b}}$ & 4.9 & 2.2 & 1.3 & - & \multirow{6}{*}{ E. crypticus } & 81 & \multirow[t]{6}{*}{$\mathrm{Pb}$ nitrate } & \multirow[t]{6}{*}{ Zhang et al. (2019b) } \\
\hline & Lufa 2.2 & 5.7 & 7.6 & 3.7 & - & & 238 & & \\
\hline & Lufa 2.3 & 5.4 & 4.0 & 1.4 & - & & 205 & & \\
\hline & Lufa 2.4 & 6.9 & 20.1 & 5.4 & - & & 948 & & \\
\hline & Lufa $5 \mathrm{M}$ & 7.0 & 10.1 & 2.6 & - & & 1008 & & \\
\hline & Grassland soil & 6.9 & 20.0 & 12.8 & - & & 991 & & \\
\hline \multirow[t]{6}{*}{ Brazil } & Oxisol & 6.1 & 5.0 & 1.6 & - & \multirow[t]{3}{*}{ E. crypticus } & 33.3 & $\mathrm{~Pb}$ acetate & Present study \\
\hline & Inceptisol & 5.7 & 6.1 & 2.9 & - & & 46 & & \\
\hline & TAS & 6.0 & - & 5.0 & - & & 19 & & \\
\hline & Oxisol & 6.1 & 5.0 & 1.6 & - & F. candida & 1169 & & \\
\hline & Inceptisol & 5.7 & 6.1 & 2.9 & - & & 2297 & & \\
\hline & TAS & 6.0 & - & 5.0 & - & & 2931 & & \\
\hline Spain & Calcic Luvisol & 7.4 & 14.3 & - & 1.2 & F. candida & 712 & $\mathrm{~Pb}$ chloride & Smolders et al. (2015) \\
\hline China & - & 6.5 & 20.1 & - & 1.6 & F. candida & 2361 & $\mathrm{~Pb}$ chloride & Xu et al. (2009) \\
\hline China & Forest soil & 5.1 & 15.2 & 1.21 & - & F. candida & 1244 & $\mathrm{~Pb}$ nitrate & Dai et al. (2020) \\
\hline Brazil & Oxisol & 6.1 & 5.0 & 1.6 & - & Z. mays & 973 & $\mathrm{~Pb}$ acetate & Present study \\
\hline & Inceptisol & 5.7 & 6.1 & 2.9 & - & & 783 & & \\
\hline & Oxisol & 6.1 & 5.0 & 1.6 & - & P. vulgaris & 357 & & \\
\hline & Inceptisol & 5.7 & 6.1 & 2.9 & - & & 511 & & \\
\hline & Rhodic Acrudox & 5.7 & 11.7 & 4.0 & - & S. bicolor $\mathrm{L}$. & 2359 & $\mathrm{~Pb}$ acetate & Cândido et al. (2020) \\
\hline & Typic Hapludox & 6.3 & 6.1 & 2.1 & - & & 2760 & & \\
\hline & Typic Hapludox & 6.3 & 6.1 & 2.1 & - & G. $\max \mathrm{L}$. & 1788 & & \\
\hline EUA & Udic Argiustolls & 4.8 & 4.1 & - & 0.4 & L. perenne $\mathrm{L}$. & 785 & $\mathrm{~Pb}$ nitrate & $\begin{array}{l}\text { Anderson and Basta } \\
\text { (2009) }\end{array}$ \\
\hline & Typic Hapludults & 5.5 & 4.1 & - & 0.7 & & 961 & & \\
\hline & Udertic Paleustolls & 6.3 & 14.2 & - & 1.4 & & 856 & & \\
\hline & Aridic Argiustolls & 7.8 & 27.9 & - & 0.7 & & 2693 & & \\
\hline & Typic Endoaquolls & 6.1 & 25.7 & - & 2.4 & & 4191 & & \\
\hline Spain & Calcic Luvisol & 7.4 & 14.3 & - & 1.2 & L. esculentum & 2900 & $\mathrm{~Pb}$ chloride & Smolders et al. (2015) \\
\hline United Kingdom & Dystric Luvisol & 6.1 & 26.5 & - & 4.3 & & 6140 & & \\
\hline Belgium & Haplic Luvisol & 6.2 & 8.4 & - & 1.0 & & 1240 & & \\
\hline Spain & Arable land & 7.4 & $14.7^{\mathrm{c}}$ & - & 1.4 & L. esculentum & 6000 & $\mathrm{~Pb}$ chloride & Cheyns et al. (2012) \\
\hline United Kingdom & Grassland & 6.5 & $27.1^{\mathrm{c}}$ & - & 3.1 & & 6500 & & \\
\hline Belgium & Arable land & 6.7 & $8.7^{\mathrm{c}}$ & - & 1.0 & & 2200 & & \\
\hline Denmark & & 5.7 & $4.2^{\mathrm{c}}$ & - & 1.5 & & 2700 & & \\
\hline Denmark & Grassland & 5.2 & $7.6^{\mathrm{c}}$ & - & 2.1 & & 1600 & & \\
\hline Netherlands & & 4.7 & $41.7^{\mathrm{c}}$ & - & 31.0 & & 5400 & & \\
\hline Belgium & Arable land & 6.7 & $8.7^{\mathrm{c}}$ & - & 1.0 & H. vulgare & 4900 & & \\
\hline
\end{tabular}


Table 5 (continued)

\begin{tabular}{|c|c|c|c|c|c|c|c|c|c|}
\hline \multirow[t]{2}{*}{ Site } & \multirow[t]{2}{*}{ Soils } & \multicolumn{4}{|c|}{ Soil properties } & \multirow[t]{2}{*}{ Species } & \multirow[t]{2}{*}{$\mathrm{EC} 0 \mathrm{mg} \mathrm{kg}^{-1}$} & \multirow[t]{2}{*}{$\mathrm{Pb}$ source } & \multirow[t]{2}{*}{ Reference } \\
\hline & & $\mathrm{pH}$ & $\begin{array}{l}\text { CEC } \\
\text { cmolc kg }\end{array}$ & $\begin{array}{l}\mathrm{OM} \\
\%\end{array}$ & $\begin{array}{l}\mathrm{OC} \\
\%\end{array}$ & & & & \\
\hline Denmark & Grassland & 5.2 & $7.6^{\mathrm{c}}$ & - & 2.1 & & 1900 & & \\
\hline Netherlands & & 4.7 & $41.7^{\mathrm{c}}$ & - & 31.0 & & 8300 & & \\
\hline \multirow[t]{3}{*}{ Spain } & Calcic Luvisol & 7.4 & 14.3 & - & 1.2 & H. vulgare & 2380 & $\mathrm{~Pb}$ chloride & Smolders et al. (2015) \\
\hline & Dystric Luvisol & 6.1 & 26.5 & - & 4.3 & & 6750 & & \\
\hline & Haplic Luvisol & 6.2 & 8.4 & - & 1.0 & & 1710 & & \\
\hline \multirow[t]{10}{*}{ Australia } & Tenosol & 7.0 & 20.9 & - & 3.0 & C. sativa $\mathrm{L}$. & 4200 & $\mathrm{~Pb}$ nitrate & Kader et al. (2016) \\
\hline & & 7.8 & 7.4 & - & 5.5 & & 3840 & & \\
\hline & & 6.3 & 24.1 & - & 8.4 & & 6250 & & \\
\hline & & 8.7 & 5.8 & - & 1.8 & & 3490 & & \\
\hline & Ferrosol & 5.2 & 5.3 & - & 3.5 & & 2240 & & \\
\hline & & 5.3 & 11.7 & - & 5.0 & & 4380 & & \\
\hline & Vertosol & 8.1 & 24.2 & - & 1.1 & & 5240 & & \\
\hline & Kurosol & 5.1 & 7.3 & - & 1.5 & & 5590 & & \\
\hline & Dermosol & 7.4 & 29.1 & - & 3.9 & & 5570 & & \\
\hline & Calcarosol & 8.1 & 19.3 & - & 3.5 & & 2560 & & \\
\hline Spain & Leptic Cambisol (eutric) & 6.7 & 9.9 & - & 0.6 & L. sativa & 3479 & $\mathrm{~Pb}$ nitrate & $\begin{array}{l}\text { Romero-Freire et al. } \\
(2015)\end{array}$ \\
\hline Spain & Leptic Regosol (eutric) & 7.2 & 25.9 & - & 8.2 & & 6240 & & \\
\hline Spain & Leptic Regosol (distric) & 5.9 & 3.8 & - & 0.5 & & 1303 & & \\
\hline Spain & $\begin{array}{l}\text { Cutanic Luvisol } \\
\text { (chromic) }\end{array}$ & 7.0 & 15.5 & - & 0.7 & & 1765 & & \\
\hline
\end{tabular}

Values are expressed in $\mathrm{mg}$ of $\mathrm{Pb} \mathrm{kg}^{-1}$ of soil

${ }^{a}$ TAS - tropical artificial soil

${ }^{\mathrm{b}}$ LUFA — Landwirtschaftliche Untersuchungs- und Forschungsanstalt, Speyer, Germany

${ }^{\mathrm{c}} \mathrm{CEC}$ - effective cation exchange capacity at soil $\mathrm{pH}$

and Hopkin 2005) for the same $\mathrm{Pb}$ amount. Thus, results from different sources of contamination may not be directly comparable. Nevertheless, the $\mathrm{EC}_{50}$ values for $F$. candida reproduction in this study, using $\mathrm{AcPb}$, are consistent with the ones reported generically for $\mathrm{Pb}$ (580 to $3160 \mathrm{mg} \mathrm{kg}^{-1}$ at $20^{\circ} \mathrm{C}$-ISO 11267:1999; Fountain and Hopkin 2005). The toxicity of $\mathrm{AcPb}$ varies among soil invertebrates due to different routes of exposure to the contaminant. Both species E. andrei and E. crypticus have soft bodies and are directly exposed through their derma, which favors the absorption of contaminants present in the soil solution (Cesar et al. 2015a). F. candida has an exoskeleton and, unlike the soft-bodied species, it absorbs the contaminant with water through specialized organs (Peijnenburg et al. 2012). These different exposure pathways may have contributed to the increased sensitivity in the soft-bodied organisms (E. andrei and E. crypticus) compared with the hard-bodied ones (F. candida) (Fig. 2). Generally, F. candida organisms have a subcylindrical or spherical body, very fragile, with a cuticle coating their exoskeleton. The exoskeleton molts can eliminate substances accumulated on the body surface, such as metals (Peijnenburg et al. 2012). Besides the dermal contact with the contaminant, the ingestion of contaminated soil organic matter should be also considered as another exposure pathway (Briones 2018).

Shoot dry matter (SDM) is the most relevant variable in toxicity tests with plants (ISO-International Organizations for Standardization 2005). It was observed that $P$. vulgaris $\mathrm{SDM}$ was the most sensitive to $\mathrm{AcPb}$ exposure in the Oxisol (Tables 4 and S2). It is known that the toxic effects of $\mathrm{Pb}$ may be due to its action in vital processes in plants, such as photosynthesis inhibition and nutrient absorption. Also, $\mathrm{Pb}$ may impair water balance, hormone status, and membrane permeability and structure (Sharma and Dubey 2005). Furthermore, several factors influence the absorption of metals such as $\mathrm{Pb}$ by plants, leading to different toxicity effects among plant species. According to Chlopecka (1994), the absorption of metals by plants is not only 
affected by contaminant concentration and form, or by soil physical and chemical attributes, but also by the characteristics of the tested plant species, nutrition, and growth stage. As most of these factors were standardized in the toxicity assays, the main differences are due to traits related to $\mathrm{Pb}$ absorption and translocation in soils (root system) and due to the attributes of the tested soils. However, it is worth remembering that little is known about the effects of acetate (in different concentrations) on the absorption of $\mathrm{Pb}$ in different plant species.

The higher $\mathrm{EC}_{50}$ values for Zea mays in the Oxisol (Tables 4 and S2) can be explained by the increased tolerance to $\mathrm{Pb}$ concentrations in soil presented by the species (Gupta et al. 2013). Some plant species, such as Brassica pekinensis and Pelargonium sp. "Frensham," present defense mechanisms when exposed to $\mathrm{Pb}$, with internal pathways for detoxification, including selective absorption, excretion, complexation by specific ligands, and compartmentalization (Arshad et al. 2008; Pourrut et al. 2011). Some species, including $\mathrm{Z}$. mays, tolerate $\mathrm{Pb}$ by complexation and inactivation, with $\mathrm{Pb}$ deposits in cell walls and vacuoles (Wierzbicka and Antosiewicz 1993). On the other hand, plant species with increased sensitivity, such as Brassica napus and Phaseolus vulgaris, have some metabolic routes blocked by $\mathrm{Pb}$ (Gupta et al. 2013).

Exposure to $\mathrm{Pb}$ reduces the capacity of nutrient absorption in plants such as Zea mays, Oryza sativa, Brassica oleracea, Raphanus sativus, and Medicago sativa (Pourrut et al. 2011). Divalent cations, including $\mathrm{Zn}^{2+}, \mathrm{Mn}^{2+}, \mathrm{Mg}^{2+}, \mathrm{Ca}^{2+}$, and $\mathrm{Fe}^{2+}$, are some of the nutrients that can have their uptake reduced by $\mathrm{Pb}$ exposure. However, factors associated with the reduction in nutrient absorption are not fully understood (Sharma and Dubey 2005; Pourrut et al. 2011). In the literature, there are reports on the several adverse effects of $\mathrm{Pb}$ on plant tissue at the subcellular level, namely chloroplasts disorganization, cell wall damage, and presence of osmiophilic bodies in stems and leaves harvested at the physiological maturity stage (Ferreyroa et al. 2017). Although these parameters were not evaluated in this study, they may have caused the observed phytotoxic effects of $\mathrm{AcPb}$.

Contrasting $\mathrm{EC}_{50}$ values were found in different soils contaminated with $\mathrm{Pb}$-nitrate and cultivated with Lolium perenne L. (ryegrass; Anderson and Basta 2009). The authors reported $\mathrm{EC}_{50}$ values between 795 and $4191 \mathrm{mg} \mathrm{Pb}$ $\mathrm{kg}^{-1}$ and attributed these differences within soils to clay, Fe oxides, and organic matter contents. The phytotoxic limit for total $\mathrm{Pb}$ in soil, i.e., $\mathrm{Pb}$ present in all soil fractions, is highly variable, ranging from 100 to $400 \mathrm{mg} \mathrm{Pb} \mathrm{kg}$ (Kabata-Pendias 2004). In most cases, $\mathrm{Pb}$ bioavailability is low, which explains the relatively high total concentrations required to induce toxicity. The variation within toxicity limits reflects differences in sorption-desorption in soils, absorption processes in the root-soil solution interface, and the sensitivity of varying species.
The acetate concentration used in the tested soils had a significant saline/toxic effect on soil invertebrates and plant species, which was proved by the AcK treatments. On the other hand, the presence of acetate as a source of organic $\mathrm{C}$ may exert a stimulant effect on soil invertebrates (Briones 2018) and may even be beneficial to Lens culinaris (lentil) plants under copper stress, with a test in 0.3 and $3.0 \mathrm{mmol} \mathrm{L}^{-1} \mathrm{Cu}$ concentrations and addition of $10 \mathrm{mmol} \mathrm{L}^{-1} \mathrm{Na}$ acetate (Hossain et al. 2020). Possibly, at lower concentrations, acetate will also present beneficial effects on $\mathrm{Pb}$ stress, and in this study the acetate concentration tested was only related to higher concentrations (acetate) that were added with $\mathrm{Pb}, 20095$ and $3200 \mathrm{mg} \mathrm{kg}^{-1}$ for invertebrates and plants, respectively. Acetate can also improve drought tolerance in plants (Kim et al. 2017), as shown with acetate environmental concentrations between 20 and $30 \mathrm{mmol} \mathrm{L}$ -1 in the soil causing enhanced drought tolerance in both monocots and dicots, such as rice, wheat, maize, and rapeseed plants, being presented as a basic and simple biochemical compound, which connects fundamental metabolism, epigenetic regulation, and hormone signaling. The absence of the benefits of acetate (AcK treatment) in this study can be explained mainly by the high acetate levels added in this treatment.

Considering the effects of $\mathrm{AcPb}$ in soils, invertebrates, and plant species, the composition and disposal of products containing $\mathrm{AcPb}$ should be carefully evaluated. Disposal of waste containing $\mathrm{AcPb}$ may represent a source of environmental contamination. The evaluation of $\mathrm{Pb}$ concentrations in plant tissue and invertebrates was not considered in the present study, but $\mathrm{Pb}$ uptake by plants and soil invertebrates likely happened, taking into consideration their reduced production, reproduction, and survival.

\section{Conclusions}

Lead acetate concentrations tested in the soils showed toxicity to at least one of the tested species (E. crypticus, $E$. andrei, F. candida, P. vulgaris, and Z. mays).

The acetate concentrations of 5320 and $12,121 \mathrm{mg} \mathrm{kg}^{-1}$ showed toxicity for plants and soil invertebrates, respectively. The effect of various acetate concentrations and its interaction with plants (including bioaccumulation phenomenon) needs to be better understood.

The lower organic matter content associated with smaller $\mathrm{CEC}$ in the Oxisol with increasing $\mathrm{AcPb}$ concentrations seem to potentiate toxicity to the studied species comparatively to the Inceptisol and the TAS.

\section{Data availability}

All data generated or analysed during this study are included in this published article and its supplementary information files. 
Acknowledgements The authors would like to thank the National Council of Technology and Scientific Development (CNPq), the Coordination for the Improvement of Higher Education Personnel (CAPES), and the Foundation for Research Support of the State of Minas Gerais (FAPEMIG) for financial support for this study. Authors also acknowledge the Environment Foundation of Minas Gerais (FEAM) and Universidade Federal de Lavras (UFLA) via cooperation term FEAM-UFLA $n^{\circ}$ 209101050013, as well as Universidade de Coimbra for the infrastructure and professionals involved in this study. Lastly, the authors thank Juliano Fernandes Mota and Paulo Roger for helping with field and laboratory activities.

Author contributions All authors contributed to the conceptualization, investigation, data analysis, and writing of the manuscript. RCSA: conceptualization, data curation, methodology, formal analysis, writing - original draft, and writing - review and editing. FRDL: writing - original draft and writing-review and editing. GCM: writing - original draft and writing-review and editing. TN: supervision, writing — original draft, and writing — review and editing. JPS: supervision, writing — original draft, and writing — review and editing. LRGG: funding acquisition and writing-review and editing. JJM: conceptualization, funding acquisition, supervision, writing-review and editing, and methodology.

Funding This study was funded by FAPEMIG, The State of Minas Gerais Research Foundation (Grant number APQ 1084/15).

\section{Compliance with ethical standards}

Conflict of interest The authors declare no competing interests.

Publisher's note Springer Nature remains neutral with regard to jurisdictional claims in published maps and institutional affiliations.

\section{References}

Alexandrino RCS, Marques JJGSM, Silva SHG, Simão FR (2020) The importance of the assessment of natural concentration of $\mathrm{Pb}$ in soils of the State of Minas Gerais. Res Soc Dev 9:8. https://doi. org/10.33448/rsd-v9i8.5022

Alloway B (2013) Heavy metals in soils: trace metals and metalloids in soils and their bioavailability. Springer, Netherlands, Dordrecht. 10.1007/978-94-007-4470-7

Alvarez VH, Ribeiro AC (1999) Calagem. In: Ribeiro AC, Guimarães PTG, Alvarez VH (eds) Recomendações para o uso de corretivos e fertilizantes em Minas Gerais: $5^{\mathrm{a}}$ aproximação. Comissão de Fertilidade do Solo do Estado de Minas Gerais, Viçosa, p 43-60

Anderson RH, Basta NT (2009) Application of ridge regression to quantify marginal effects of collinear soil properties on phytotoxicity of arsenic, cadmium, lead, and zinc. Environ Toxicol Chem 28:1018-1027. https://doi.org/10.1897/08-062.1

Ardestani MM, van Straalen NM, van Gestel CAM (2014) Uptake and elimination kinetics of metals in soil invertebrates: a review. Environ Pollut 193:277-295. https://doi.org/10.1016/j.envpol. 2014.06.026

Arshad M, Silvestre J, Pinelli E, Kallerhoff J, Kaemmerer M, Tarigo A, Shahid M, Guiresse M, Pradere P, Dumat C (2008) A field study of lead phytoextraction by various scented Pelargonium cultivars. Chemosphere 71:2187-2192. https://doi.org/10.1016/j. chemosphere.2008.02.013

Bartlett MS (1937) Properties of sufficiency and statistical tests. Proc R Soc A 160:268-282. https://doi.org/10.1098/rspa.1937.0109
Briones MJI (2018) The serendipitous value of soil fauna in ecosystem functioning: the unexplained explained. Front Environ Sci 149:1-11. https://doi.org/10.3389/fenvs.2018.00149

Brown SL, Chaney RL, Hettiarachchi GM (2016) Lead in urban soils: a real or perceived concern for urban agriculture? J Environ Qual 45:26-36. https://doi.org/10.2134/jeq2015.07.0376

Bur T, Crouau Y, Bianco A, Gandois L, Probst A (2012) Toxicity of $\mathrm{Pb}$ and of $\mathrm{Pb} / \mathrm{Cd}$ combination on the springtail Folsomia candida in natural soils: reproduction, growth and bioaccumulation as indicators. Sci Total Environ 414:187-197. https://doi.org/10. 1016/j.scitotenv.2011.10.029

Cândido GS, Martins GC, Vasques ICF, Lima FRD, Pereira P, Engelhardt MM, Reis RHCL, Marques JJ (2020) Toxic effects of lead in plants grown in Brazilian soils. Ecotoxicology 29:305-313. https://doi.org/10.1007/s10646-020-02174-8

Cesar R, Rodrigues AP, Bidone E, Castilhos Z, Polivanov H, Campos $T$ (2015a) Proposta de um índice de risco ecológico para disposição sustentável de sedimentos de dragagem em Latossolos e Chernossolos. Geociências 34:275-285

Cesar R, Natal-da-Luz T, Silva F, Bidone E, Castilhos Z, Polivanov H, Sousa JP (2015b) Ecotoxicological assessment of a dredged sediment using bioassays with three species of soil invertebrates. Ecotoxicology 24:414-423. https://doi.org/10.1007/s10646-014$1390-8$

Chandrasekhar C, Ray JG (2019) Lead accumulation, growth responses and biochemical changes of three plant species exposed to soil amended with different concentrations of lead nitrate. Ecotox Environ Safe 171:26-36. https://doi.org/10.1016/j. ecoenv.2018.12.058

Chelinho S, Domene X, Campana P, Andrés P, Römbke J, Sousa JP (2014) Toxicity of phenmedipham and carbendazim to Enchytraeus crypticus and Eisenia andrei (Oligochaeta) in Mediterranean soils. J Soils Sediments 14:584-599. https://doi.org/10. 1007/s11368-013-0818-8

Cheyns K, Peeters S, Delcourt D, Smolders E (2012) Lead phytotoxicity in soils and nutrient solutions is related to lead induced phosphorus deficiency. Environ Pollut 164:242-247. https://doi. org/10.1016/j.envpol.2012.01.027

Chlopecka A (1994) Forms of $\mathrm{Cd}, \mathrm{Cu}, \mathrm{Pb}$, and $\mathrm{Zn}$ in soil and their uptake by cereal crops when applied jointly as carbonates. Water Air Soil Pollut 87:297-309. https://doi.org/10.1007/BF00696843

Dai W, Holmstrup M, Slotsbo S, Ke X, Li Z, Gao M, Wu L (2020) Compartmentation and effects of lead $(\mathrm{Pb})$ in the collembolan, Folsomia candida. Environ Sci Pollut Res 27:43638-43645. https://doi.org/10.1007/s11356-020-10300-6

Davies NA, Hodson ME, Black S (2002) Changes in toxicity and bioavailability of lead in contaminated soils to the earthworm Eisenia fetida (Savigny 1826) after bone meal amendments to the soil. Environ Toxicol Chem 21:2685-2691. https://doi.org/10. 1002/etc.5620211222

Davies NA, Hodson ME, Black S (2003) The influence of time on lead toxicity and bioaccumulation determined by the OECD earthworm toxicity test. Environ Pollut 121:55-61. https://doi.org/10. 1016/S0269-7491(02)00207-5

Day PR (1965) Particle fractionation and particle-size analysis. In: Black CA (ed) Methods of soil analysis: physical and mineralogical properties including statistics of measurement and sampling, part 1. American Society of Agronomy, Madison, $p$ 545-567. 10.2134/agronmonogr9.1.c43

Dunnett CW (1955) A multiple comparison procedure for comparing several treatments with a control. J Am Stat Assoc 50 (272):1096-1121. https://doi.org/10.1080/01621459.1955.10501294

EC - Environment Canada (2007) Guidance document on statistical methods for environmental toxicity tests. Environment Canada, Ottawa. http://publications.gc.ca/site/eng/278313/publication.html. Accessed 20 Dec 2018. 
Entwistle JA, Amaibi PM, Dean JR, Deary ME, Medock D, Morton J, Rodushkin I, Bramwell L (2019) An apple a day? Assessing gardeners' lead exposure in urban agriculture sites to improve the derivation of soil assessment criteria. Environ Int 122:130-141. https://doi.org/10.1016/j.envint.2018.10.054

FAO - Food and Agriculture Organization of The United Nations (2018) Soil pollution: a hidden reality. FAO, Rome. http://www. fao.org/3/I9183EN/i9183en.pdf. Accessed 20 Dec 2018

Ferreyroa GV, Lagorio MG, Trinelli MA, Lavado RS, Molina FV (2017) Lead effects on Brassica napus photosynthetic organs. Ecotoxicol Environ Saf 140:123-130. https://doi.org/10.1016/j. ecoenv.2017.02.031

Fountain MT, Hopkin SP (2005) Folsomia candida (collembola): a "standard" soil arthropod*. Annu Rev Entomol 50:201-222. https://doi.org/10.1146/annurev.ento.50.071803.130331

Frank JJ, Poulakos AG, Tornero-Velez R, Xue J (2019) Systematic review and meta-analyses of lead $(\mathrm{Pb})$ concentrations in environmental media (soil, dust, water, food, and air) reported in the United States from 1996 to 2016. Sci Total Environ 694:133489. https://doi.org/10.1016/j.scitotenv.2019.07.295

Garcia MVB, Roembke J, Martius C (2004) Proposal for an artificial soil substrate for toxicity tests in tropical regions. In: Proceedings of the 25th Annual Meeting of Society of Environmental Toxicology and Chemistry-SETAC, Portland

Gardi C, Angelini M, Barceló S, Comerma J, Gaistardo CC, Rojas AE, Jones A, Krasilnikov P, Mendonça-Santos ML, Montanarella L, Muñiz Ugarte O, Schad P, Rodríguez MIV, Vargas R, da Silva MR (2015) Atlas de Solos de América Latina e do Caribe. Comissão Europeia-Serviço de Publicações da União Europeia, Luxembourg, p 176

Guevara YZC, Souza JJLL, Veloso GV, Veloso RW, Rocha PA, Abrahão WAP, Fernandes Filho EI (2018) Reference values of soil quality for the Rio Doce Basin. Rev Bras Ciência do Solo 42:1-16. https://doi.org/10.1590/18069657rbcs20170231

Gupta DK, Corpas FJ, Palma JM (2013) Heavy metal stress in plants. Springer, Berlin. 10.1007/978-3-642-38469-1

Haouas Z, Sallem A, Zidi I, Hichri H, Mzali I, Mehdi M (2014) Hepatotoxic effects of lead acetate in rats: histopathological and cytotoxic studies. J Cytol Histol 5:256. https://doi.org/10.4172/ 2157-7099.1000256

Harter RD (1983) Effect of soil pH on adsorption of lead, copper, zinc, and nickel. Soil Sci Soc Am J 7:47-51. https://doi.org/10.2136/ sssaj1983.03615995004700010009x

Hossain MS, Abdelrahman M, Tran CD, Nguyen KH, Chu HD, Watanabe Y, Hasanuzzaman M, Mohsin SM, Fujita M, Tran LSP (2020) Insights into acetate-mediated copper homeostasis and antioxidant defense in lentil under excessive copper stress. Environ Pollut 258:113544. https://doi.org/10.1016/j.envpol. 2019.113544

Ibrahim NM, Eweis EA, El-Beltagi HS, Abdel-Mobdy YE (2012) Effect of lead acetate toxicity on experimental male albino rat. Asian Pac J Trop Biomed 2:41-46. https://doi.org/10.1016/ s2221-1691(11)60187-1

ISO-International Organizations for Standardization (1999) Soil quality: inhibition of reproduction of Collembola (Folsomia candida) by soil pollutants. ISO, Geneva. ISO 11267

ISO-International Organizations for Standardization (1998) Soil quality - effects of pollutants on earthworms (Eisenia fetida): part 2 , determination of effects on reproduction. ISO, Geneva. ISO $11268-2$

ISO-International Organizations for Standardization (2005) Soil quality: determination of the effects of pollutants on soil flora: part 2, effects of contaminated soil on the emergence and early growth of higher plants. ISO, Geneva. ISO 11269-2

ISO-International Organizations for Standardization (2004) Soil quality—effects of pollutants on Enchytraeidae (Enchytraeus sp.)
- determination of effects on reproduction and survival. ISO, Geneva, ISO 16387

Jie X, Yin W, Yong-Ming L, Jing S, Xin K (2009) Effects of cooper, lead and zinc in soil on egg development and hatching of Folsomia candida. J Insect Sci 16:51-55. https://doi.org/10.1111/j. 1744-7917.2009.00253.x

Kabata-Pendias A (2004) Soil-plant transfer of trace elements: an environmental issue. Geoderma 122:143-149. https://doi.org/10. 1016/j.geoderma.2004.01.004

Kabata-Pendias A, Mukherjee AB (2007) Trace elements from soil to human. Springer-Verlag, New York, NY, p 9-38

Kader M, Lamb DT, Mahbub KR, Megharaj M, Naidu R (2016) Predicting plant uptake and toxicity of lead $(\mathrm{Pb})$ in long-term contaminated soils from derived transfer functions. Environ Sci Pollut Res 23:15460-15470. https://doi.org/10.1007/s11356-0166696-z

Kim JM, To TK, Matsui A et al. (2017) Acetate-mediated novel survival strategy against drought in plants. Nat Plants 3:17097. https://doi.org/10.1038/nplants.2017.97

Kruskal WH, Wallis WA (1952) Use of ranks in one-criterion variance analysis. J Am Stat Assoc 47:583-621. https://doi.org/10.2307/ 2280779

Li C, Zhu Z, Wang Y, Guo Q, Wang C, Zhong P, Tan Z, Yang R (2020) Lead acetate produced from lead-acid battery for efficient perovskite solar cells. Nano Energy 69:104380. https://doi.org/ 10.1016/j.nanoen.2019.104380

Li M, Zhang R, Guo Y, Huan Y, Xi J, Bai Z, Ya X (2018) Introducing lead acetate into stoichiometric perovskite lewis acid-based precursor for improved solar cell photovoltaic performance. J Alloys Compd 767:829-837. https://doi.org/10.1016/j.jallcom.2018.07. 190

Liao M, Chen CL, Zeng LS, Huang CY (2007) Influence of lead acetate on soil microbial biomass and community structure in two different soils with the growth of Chinese cabbarge (Brassica chinensis). Chemosphere 66:1197-1205. https://doi.org/10.1016/ j.chemosphere.2006.07.046

Lock K, Janssen CR (2003) Multi-generation toxicity of zinc, cadmium, copper and lead to the potworm Enchytraeus albidus. Environ Pollut 117:89-92. https://doi.org/10.1016/S0269-7491 (01)00156-7

Malavolta E (1980) Elementos de nutrição mineral de plantas. Agronômica Ceres, São Paulo

Menta C, Maggiani A, Vattuone Z (2006) Effects of Cd and Pb on the survival and juvenile production of Sinella coeca and Folsomia candida. Eur J Soil Biol 42:181-189. https://doi.org/10.1016/j. ejsobi.2006.01.001

Neuhauser EF, Loehr RC, Milligan DL, Malecki MR (1985) Toxicity of metals to the earthworm Eisenia fetida. Biol Fertil Soils 1:149-152. https://doi.org/10.1007/BF00301782

NTP - National Toxicology Program (2016) Report on carcinogens, fourteenth edition. U.S. Department of Health and Human Services, Public Health Service, Research Triangle Park, NC. https:// ntp.niehs.nih.gov/go/roc14. Accessed 10 Dec 2020.

Päivöke AE (2002) Soil lead alters phytase activity and mineral nutrient balance of Pisum sativum. Environ Exp Bot 48:61-73. https://doi.org/10.1016/S0098-8472(02)00011-4

Penha JG, Carvalho GS, de Abreu LB, Ribeiro BT, de Souza CET, Marques JJ (2017) Procedimentos para quantificação de elementos traço por espectrofotometria de absorção atômica em matrizes de interesse ambiental. Editora UFLA, Lavras, 10.13140/RG.2.2.24948.55685

Peijnenburg W, Capri E, Kula C, Liess M, Luttik R, Montforts M, Nienstedt K, Römbke J, Sousa JPJensen J,(2012) Evaluation of exposure metrics for effect assessment of soil invertebrates Crit Rev Environ Sci Technol 42:1862-1893. 10.1080/ 10643389.2011.574100 
Pierangeli MAP, Guilherme LRG, Curi N, Silva MLN, Oliveira LR, Lima JD (2001a) Efeito do pH na adsorção-dessorção de chumbo em Latossolos brasileiros. Rev Bras Cienc Solo 25:269-277. https://doi.org/10.1590/s0100-06832001000200003

Pierangeli MAP, Guilherme LRG, Oliveira LR, Curi N, Silva MLN (2001b) Efeito da força iônica da solução de equilíbrio sobre a adsorção/dessorção de chumbo em Latossolos brasileiros. Pesq Agropec Bras 36:1077-1084. https://doi.org/10.1590/S0100204X2003000600010

Pohanish RP (2017) Sittig's handbook of toxic and hazardous chemicals and carcinogens. Elsevier, Amsterdam, p 1725-1728

Pourrut B, Shahid M, Dumat C, Winterton P, Pinelli E (2011) Lead uptake, toxicity, and detoxification in plants. Rev Environ Contam Toxicol 213:113-136. https://doi.org/10.1007/978-1-4419-9860-6_4

Rees N, Fuller R (2020) The toxic truth: children's exposure to lead pollution undermines a generation of future potential, 2nd edn. UNICEF and Pure Earth. https://www.unicef.org/media/73246/ file/The-toxic-truth-children $\%$ E2\%80\%99s-exposure-to-leadpollution-2020.pdf. Accessed 20 Dec 2020

Rehman ZU, Khan S, Brusseau ML, Shah MT (2017) Lead and cadmium contamination and exposure risk assessment via consumption of vegetables grown in agricultural soils of five-selected regions of Pakistan. Chemosphere 168:1589-1596. https://doi. org/10.1016/j.chemosphere.2016.11.152

Romero-Freire A, Martin Peinado FJ, van Gestel CAM (2015) Effect of soil properties on the toxicity of $\mathrm{Pb}$ : assessment of the appropriateness of guideline values. J Hazard Mater 289:46-53. https://doi.org/10.1016/j.jhazmat.2015.02.034

Sandifier RD, Hopkin SP (1997) Effects of temperature on the relative toxicities of $\mathrm{Cd}, \mathrm{Cu}, \mathrm{Pb}$, and $\mathrm{Zn}$ to Folsomia candida (Collembola). Ecotoxicol Environ Saf 37:125-130. https://doi.org/10. 1006/eesa.1997.1536

Sharma P, Dubey RS (2005) Lead toxicity in plants. Braz J Plant Physiol 17:35-52. https://doi.org/10.1590/S1677-04202005000100004

Selwyn L (2017) How to test for sulfur in materials using lead acetate test paper-Canadian Conservation Institute (CCI) Notes 17/5 (ISSN 1928-1455). Government of Canada, Canadian Conservation Institute. https://www.canada.ca/en/conservationinstitute/services/conservation-preservation-publications/canadia n-conservation-institute-notes/test-sulfur-acetate-paper.html. Accessed 10 Dec 2020

Smolders E, Oorts K, Peeters S, Lanno R, Cheyns K (2015) Toxicity in lead salt spiked soils to plants, invertebrates and microbial processes: unraveling effects of acidification, salt stress and ageing reactions. Sci Total Environ 536:223-231. https://doi.org/ 10.1016/j.scitotenv.2015.07.067

Spurgeon DJ, Hopkin SP, Jones DT (1994) Effects of cadmium, copper, lead and zinc on growth, reproduction and survival of the earthworm Eisenia fetida (Savigny): assessing the environmental impact of point-source metal contamination in terrestrial ecosystems. Environ Pollut 84:123-130. https://doi.org/10.1016/ 0269-7491(94)90094-9
Statsoft INC (2004) Statistica: data analysis software system, version 7. Tulsa. http://www.statsoft.com/. Accessed 20 Dec 2018

Sobolev D, Begonia M (2008) Effects of heavy metal contamination upon soil microbes: lead-induced changes in general and denitrifying microbial communities as evidenced by molecular markers. Int J Environ Res Public Health 5:450-456. https://doi.org/ 10.3390/ijerph5050450

Soil Survey Staff (2014) Keys to soil taxonomy, 12th edn. U.S. Department of Agriculture, Natural Resources Conservation Service, Washington

Teixeira WG, Viana JHM, Donagemma GK (2017) Manual de métodos de análise de solo, 3rd edn. Empresa Brasileira de Pesquisa Agropecuária (EMBRAPA), Brasília. https://www.infoteca.cnptia. embrapa.br/handle/doc/1085209. Accessed 20 Dec 2020.

U.S. Environmental Protection Agency - USEPA (2007) Method 3051A (SW-846): microwave assisted acid digestion of sediments, sludges, and oils. USEPA, Washington

Verma J, Kumari S, Dhasmana A (2020) Toxic effect of Lead on earth's life. IJIRT 7:673-676. https://doi.org/10.6084/m9.figsha re. 12472106

Wani AL, Ara A, Usmani JA (2015) Lead toxicity: a review. Interdiscip Toxicol 8:55-64. https://doi.org/10.1515/intox2015-0009

Walkley A, Black IA (1934) An examination of the Degtjareff method for determining soil organic matter and a proposed modification of the chromic acid titration method. Soil Sci 37:29-38

Wierzbicka M, Antosiewicz D (1993) How lead can easily enter the food chain - a study of plant roots. Sci Total Environ 134:423-429. https://doi.org/10.1016/S0048-9697(05)80043-9

WHO - World Health Organization (2019) Exposure to lead: a major public health concern, WHO/CED/PHE/EPE/19.4.7. https://apps. who.int/iris/bitstream/handle/10665/329953/WHO-CED-PHEEPE-19.4.7-eng.pdf?ua=1. Accessed 20 Dec 2020

Xu J, Wang Y, Luo YM, Song J, Ke X (2009) Effects of copper, lead and zinc in soil on egg development and hatching of Folsomia candida. Insect Sci 16:51-55. https://doi.org/10.1111/j.17447917.2009.00253.x

Zeng LS, Liao M, Chen CL, Huang CY (2007) Effects of lead contamination on soil enzymatic activities, microbial biomass, and rice physiological indices in soil-lead-rice (Oryza sativa L.) system. Ecotoxicol Environ Saf 67:67-74. https://doi.org/10. 1016/j.ecoenv.2006.05.001

Zhang L, Muccillo VBS, Van Gestel CA (2019a) A combined toxicokinetics and toxicodynamics approach to investigate delayed lead toxicity in the soil invertebrate Enchytraeus crypticus. Ecotoxicol Environ Saf 169:33-39. https://doi.org/10.1016/j. ecoenv.2018.10.084

Zhang L, Verweij RA, Van Gestel CAM (2019b) Effect of soil properties on $\mathrm{Pb}$ bioavailability and toxicity to the soil invertebrate Enchytraeus crypticus. Chemosphere 217:9-17. https://doi. org/10.1016/j.chemosphere.2018.10.146 